\title{
PEMANFAATAN TANAMAN HERBAL SEBAGAI PHYTOBIOTIK PADA KELOMPOK PETERNAK BROILER DI DESA AKEKOLANO KECAMATAN OBA UTARA UNTUK MENDORONG KETERSEDIAAN DAGING BROILER ORGANIK DI PROVINSI MALUKU UTARA
}

\author{
Yusri Sapsuha', Nurhasanah ${ }^{2}$, Indah Rodianawati $^{3}$ dan Hasriani Ishak ${ }^{4}$ \\ ${ }^{1}$ Program Studi Peternakan Fakultas Pertanian UNKHAIR \\ ${ }^{2}$ Program Studi Pendidikan Biologi FKIP UNKHAIR \\ ${ }^{3)}$ Program Studi THP Fakultas Pertanian UNKHAIR \\ ${ }^{4}$ Program Studi Pendidikan Matematika FKIP UNKHAIR \\ ${ }^{1}$ Email : yus_ara01@yahoo.co.id
}

\begin{abstract}
The purpose of the is to maximize the use of agricultural and fisheries wastes in North Maluku as broilerfeed in order to reduce the price of feed, as well as utilizing herbs such as turmeric nutmeg leaf (Myristica frangrans Houtt) and clove (Syzygium aromaticum L) as a substitute for phytobiotic antibiotics for organic broiler to obtain a healthy and safe for consumption. Extensive use of antibiotics lead to residues in livestock products. Microbial resistance in human pathogens to antibiotics is a major public health problem. The livestock industrymust reduce the use of antibiotics in animal production and seek other alternatives for disease control to replace the use of antibiotics. Herbs can be used as a substitute for antibioticsphytobiotic. The results showed that the use of waste of agriculture and fisheries activities as well as herbs in broiler feed can increase productivity and reduce production costs
\end{abstract}

Keywords: organic broiler, phytobiotic, antibiotics, feed plan 


\section{PENDAHULUAN}

Pangan asal hewani terutama broiler yang dikonsumsi sehari-hari akan menjadi tidak aman dan beresiko karena kemungkinan mengandung bahan berbahaya seperti residu obat hewan, atau bahan kimia berbahaya lainnya. Pengobatan dengan antibiotik selan mahal dapat berdampak negatif terhadap kesehatan apabila produk hasil ternak yang dihasilkan mengandung residu. Resistensi mikroba patogen pada manusia terhadap antibiotik merupakan masalah utama kesehatan masyarakat, industri peternakan harus mengurangi penggunaan antibiotik pada hewan produksi dan mencari alternatif lain dalam pengendalian penyakit untuk menggantikan pemakaian antibiotik.

Bahan dasar ransum unggas pada dasarnya bersaing dengan kebutuhan manusia. Hal tersebut mengakibatkan harga ransum meningkat dan menjadi kendala bagi perternakan rakyat yang baru berkembang. Salah satu upaya untuk mengatasi kendala tersebut adalah dengan memanfaatkan bahan ransum non konvensional yang mudah ditemukan di sekitar wilayah peternakan. Daun lamtoro (Leucaena leucocephala), kelor (Moringa oleifera) dan gamal (Gliricidia sepium) merupakan jenis daun dari tanaman leguminosa yang bayak ditemukan di Maluku Utara serta limbah ikan dan limbah pertanian laiinya.

Leguminosa termasuk jenis tanaman pohon dan perdu yang tidak dapat dijangkau ternak. Pemanfaatan tanaman leguminosa sebagai bahan ransum unggas membutuhkan bantuan manusia. Daun-daun dari jenis tanaman ini dapat diolah menjadi tepung daun sehingga dapat dikonsumsi oleh ayam broiler. Meskipun penambahan tepung daun dibatasi dalam formulasi ransum tetapi diharapkan dapat meningkatkan efesiensi biaya produksi.

Hasil analisa gizi khususnya kandungan protein kasar tepung daun lamtoro (Leucaena leucocephala), kelor (Moringa oleifera) dan gamal (Gliricidia sepium) berturut-turut adalah $9,05 \%, 13,05 \%$ dan 11,03\% (Sapsuha dan Sjafani, 2011). Berdasarkan potensi gizi tersebut maka secara kuantitatif tepung daun lamtoro (Leucaena leucocephala), kelor (Moringa oleifera) dan gamal (Gliricidia sepium) dapat dijadikan sebagai bahan ransum ayam broiler.
Pemanfaatan phytobiotik sebagai Natural Growth Promotor atau NGPs telah diidentifikasi sebagai alternatif yang efektif untuk antibiotik. Phytobiotik sebagai NGPs sangat berkembang sebagai feed additive, immunitas, meningkatkan performa dan sangat efektif dalam meningkatkan kesehatan saluran pencernaan (Panda et al., 2009). Pemanfaatan phytobiotik dalam ransum sebagai kandidat probiotik belum banyak yang meneliti. Penelitian ini dilakukan dengan tujuan ingin mengetahui potensi kombinasi serbuk pala dan cengkeh sebagai phytobiotik sebagai kandidat probiotik yang diisolasi dari saluran pencernaan broiler yang pada akhirnya akan menghasilkan produk berupa probiotik yang bertujuan untuk meningkatkan produktivitas dan kualitas broiler dan sebagai NGPs.

Phytobiotik adalah imbuhan pakan yang berasal dari produk turunan tanaman yang digunakan dalam pakan ternak yang bertujuan untuk meningkatkan performa dari ternak tersebut (Windisch et al., 2008). Zat aktif yang berasal dari tanaman obat pada umumnya ditemukan dalam bentuk metabolit sekunder. Satu tanaman obat biasanya menghasilkan lebih dari satu jenis metabolit sekunder (phytoalexins, asam organik, minyak atsiri dan antioksidan) sehingga dalam satu tanaman obat memungkinkan untuk memiliki lebih dari satu efek farmakologi. Kombinasi beberapa jenis bahan aktif menunjukan efektifitas kerja yang lebih tinggi dibandingkan penggunaan bahan aktif tunggal (Ulfah, 2006).

Penggunaan Additive tepung daging buah pala (Myristica fragrans Houtt ) (Utami, 2011) memberikan respon positif terhadap kinerja ayam broiler pada kepadatan kandang yang berbeda, sedang menurut US Food and Drugs Adminsitrative (FDA), minyak pala dikenal sebagai GRAS (Generally Recognize As Safe), yang digunakan sebagai minyak atsiri, oleoresin (bebas pelarut), dan ekstrak alami (termasuk destilat) (CFR, 2005), oleh karena potensi farmakologi yang dimilikinya, minyak pala dimanfaatkan sebagai bahan antibakteri (Ojechi et al., 1993).

Ayam broiler merupakan salah satu jenis ternak yang mempunyai kemampuan tinggi dalam mengkonversi ransum yang dikonsumsinya menjadi daging. Sehingga dengan cepat dapat 
memenuhi kebutuhan masyarakat akan protein hewani. Pemakaian antibiotik yang luas menyebabkan residu dalam produk ternak. Resistensi mikroba patogen pada manusia terhadap antibiotik merupakan masalah utama kesehatan masyarakat. Industri peternakan harus mengurangi penggunaan antibiotik (Conway and Wang, 2000) pada hewan produksi dan mencari alternatif lain dalam pengendalian penyakit untuk menggantikan pemakaian antibiotik. Probiotik dapat meningkatkan kesehatan individu dan berbeda dengan antibiotik, probiotik tidak menimbulkan residu dan resistensi (Lopez, 2000).

Pelaksanaan kegiatan IPTEKDA LIPI Tahun 2016 ini dilakukan untuk memanfaatkan potensi fitobiotik buah pala (Myristica frangrans Houtt) dan cengkeh (Syzygium aromaticum L) serta memanfaatkan limbah sisa hasil pertanian dan perikanan sebagai pakan broiler untuk meningkatkan kesejahteran kelompok peternak broiler di Desa Akekolano Kecamatan Oba Utara Kota Tidore Kepulauan.

\section{METODE PELAKSANAAN}

\subsection{Bahan Baku}

a. DOC Broiler

DOC yang digunakan dalam program ini adalah ayam broiler berumur sehari (DOC) yang tidak dibedakan jenis kelaminnya (unsex) yang diperoleh dari UD. Tani Satwa sebagai Mitra Kerja dalam kegiatan ini.

b. Konsentrat

Konsentrat dibutuhkan sebagai bahan baku pakan penyusun ransum ampas tahu, onggok, jagung, bungkil kelapa, dedak, premix (mineral mikro dan vitamin A, D, dan E). Bahan-bahan tersebut banyak dijumpai di masyarakt sekitar kampus.

\subsection{Proses Produksi}

Pemeliharaan ayam broiler dilakukan didalam kandang panggung berkapasitas 1000 ekor. Peralatan yang digunakan adalah perlengkapan makan dan minum, alat kesehatan, timbangan pakan dan ternak, sekop, garpu, sapu lidi, tambang dan pompa air. Pada tahun pertama 5.000 ekor DOC akan dipelihara selama 5 periode dimana setiap periode sebanyak 1000 ekor. Proses produksi dari kegiatan IPTEKDA LIPI ini dapat dilihat pada Gambar 1.

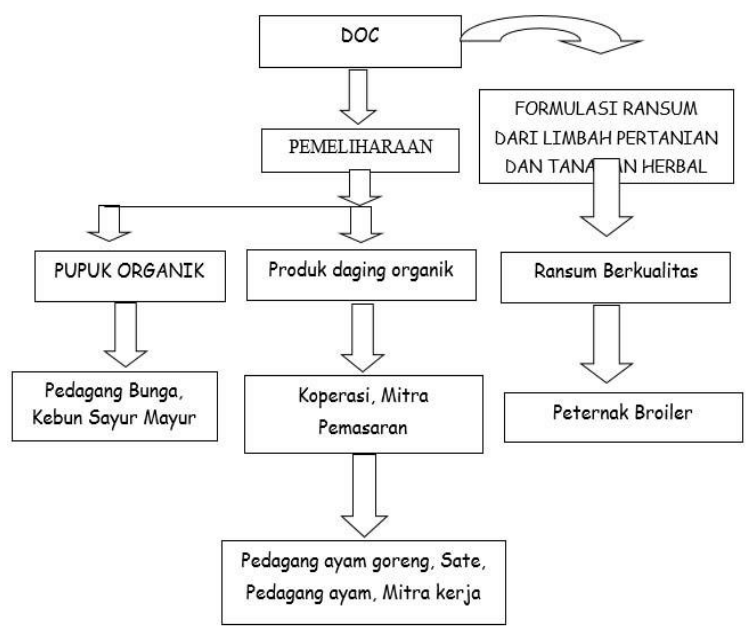

Gambar 1. Bagan Alur Produksi Kegiatan IPTEKDA LIPI

\subsection{Pemasaran}

Pemasaran untuk produk broiler dilakukan kepada:

1. Pedagang pengumpul ternak di wilayah Kota Sofifi (mitra kerja). Pedagang pengumpul ini yang menjualnya kepada masyarakat di Kota Sofifi dan daerah lain di Propinsi Maluku Utara (Halmahera, Kota Tidore, Kab, Kepulauan Sula dan sebagainya).

2. Memasarkan produk untuk memenuhi permintaan hotel/café/restorant di Kota Sofifi.

3. Untuk pemasaran produk sampingan berupa pupuk organik dikhususkan pada perorangan (pedagang bunga, rumah tangga). Skematik rencana jalur pemasaran disajikan pada Gambar 2.

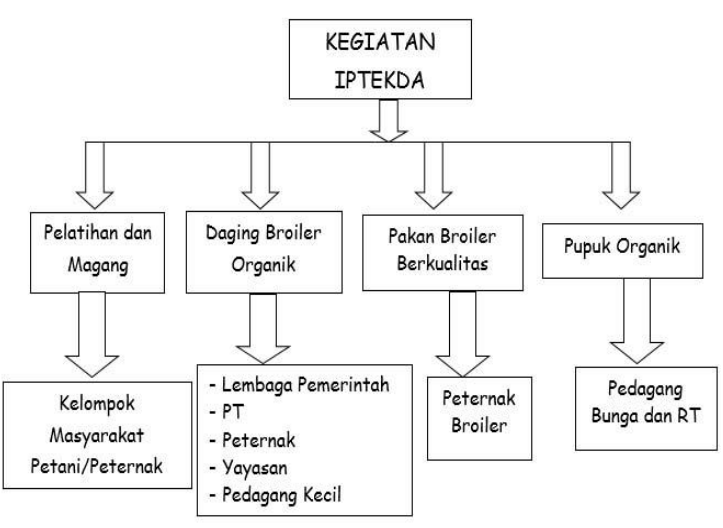

Gambar 2. Jalur Pemasaran IPTEKDA LIPI 


\section{HASIL DAN PEMBAHASAN}

\subsection{Kondisi UMKM}

Jumlah UMKM yang terlibat dalam kegiatan ini adalah 1 (satu) kelompok, yaitu kelompok peternak Sejahtera, dengan alamat Desa Akekolano Kecamatan Oba Utara Kota Tidore Kepulauan. Landasan yang melatarbelakangi pemilihan kelompok tersebut adalah adanya antusiasme dan motivasi yang kuat dari kelompok tersebut untuk dapat mengembangkan usaha beternak ayam broiler. Selama ini mereka hanya melakukan pemeliharaan dengan kapasitas produyksi yang sangat kecil antara 300 - 500 ekor karena terkendala biaya pakan yang sangat mahal. Oleh karena itu untuk menekan biaya pakan maka akan digunakan bahan limbah pertanian dan perikanan sebagai pakan dengan melalui teknologi formulasi pakan yang sesuai dengan kebutuhan nutrisi ternak broiler.

Adanya mesin penggiling pakan dan mesin pencampur pakan diharapkan mampu memproduksi pakan berkualitas sehingga dapat mengurangi biaya pakan, mengingat biaya pakan dipasaran sekarang dikisaran Rp. 10.000/ kg.

Calon mitra kerja merupakan kelompok usaha yang sudah lama memelihara ternak broiler, dengan demikian pengalaman dan kemampuan mitra dalam beternak broiler tidak diragukan lagi. Diharapkan dengan adanya sentuhan teknologi, maka pengetahuan dan kemampuan calon mitra menjadi semakin berkembang.

\subsection{Pelaksana Kegiatan}

Kegiatan Iptekda ini telah di laksakanan di Desa Akekolano Kecamatan Oba Utara. Teknologi yang telah diintroduksikan kepada UMKM ini adalah pemanfaatan tanaman herbal sebagai fitobiotik untuk mengurangi pemakaian antibiotik pada ternak broiler guna menekan biaaya produksi dan menghasilkan daging broiler organik yang aman di konsumsi karena tidak mengandung residu obat-obatan yang digunakan peternak broiler pada umumnya. Tanaman herbal yang digunakan pada kegiatan IPTEKDA LIPI 2016 di Desa Akekolano ini adalah buah Pala (Myristica frangrans Houtt) dan Cengkeh (Syzygiumaromaticum $\mathrm{L}$ ) yang dibuat tepung dan dicampurkan pada pakan dengan doses penberian $2 \%$ dari total ransum.
Adapun kegiatan yang telah dilaksanakan antara lain :

\section{Pengadaan Mesin}

Pembelian mesin masing-masing satu unit antara lain mesin penggiling pakan, mesin pencampur pakan, mesin pencabut bulu dan frizer seperti pada gambar 1 berikut :

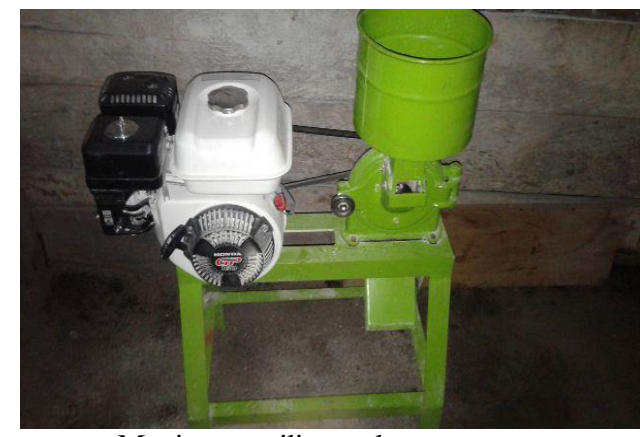

Mesin penggiling pakan

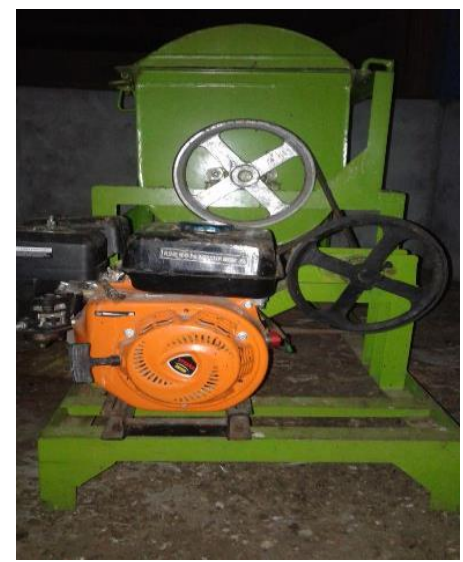

Mesin pencampur pakan

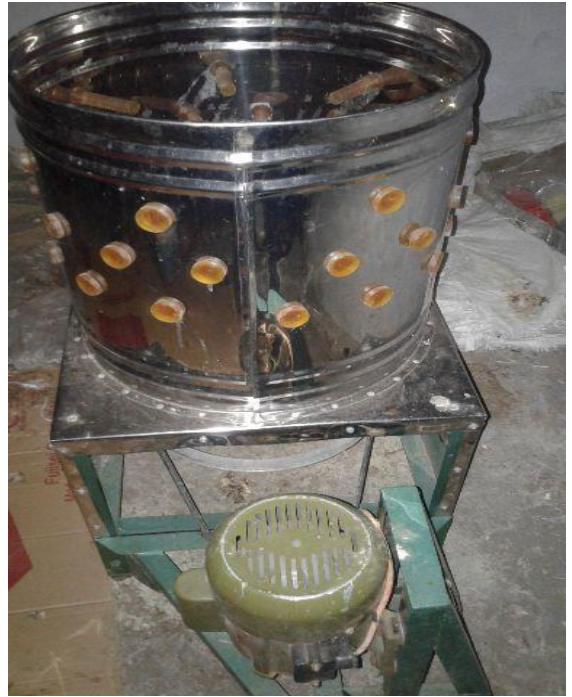

Mesin pencabut bulu 


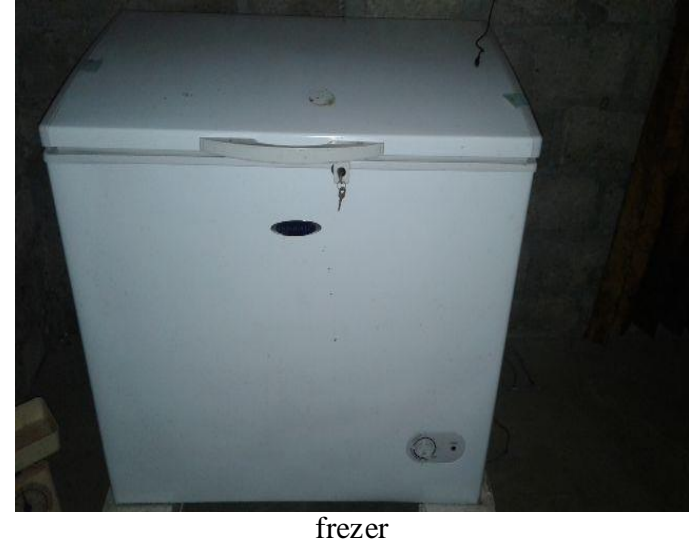

Gambar 3. Pembelian mesin pengiling pakan, mesin pencampur pakan, mesin pencabut bulu dan frizer

2. Pemeliharaan broiler

Pemeliharaan broiler telah dilaksanakan semenjak bulan Februari 2016, seperti pada Gambar 2 berikut ini.
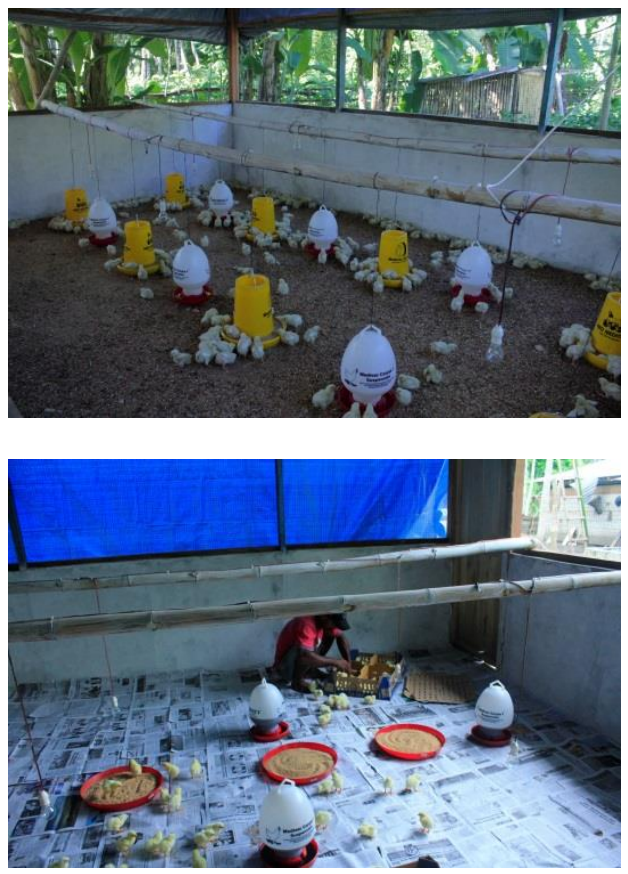

Gambar 4. Pemeliharaan Ayam Broiler

3. Pemanfaatan tananam herbal sebagai fitobiotik

Fitobiotik adalah imbuhan pakan yang berasal dari produk turunan tanaman yangdigunakan dalam pakan ternak yang bertujuan untuk meningkatkan performa dari ternak tersebut (Windisch et al., 2008).Kombinasibeberapa jenis bahan aktif menunjukan efektifitas kerja yang lebih tinggi dibandingkanpenggunaan bahan aktif tunggal (Ulfah, 2006).Tanaman herbal yang digunakan pada kegiatan IPTEKDA LIPI 2016 di Desa Akekolano ini adalah buah Pala (Myristica frangrans Houtt) dan Cengkeh (Syzygium aromaticum $\mathrm{L}$ ).
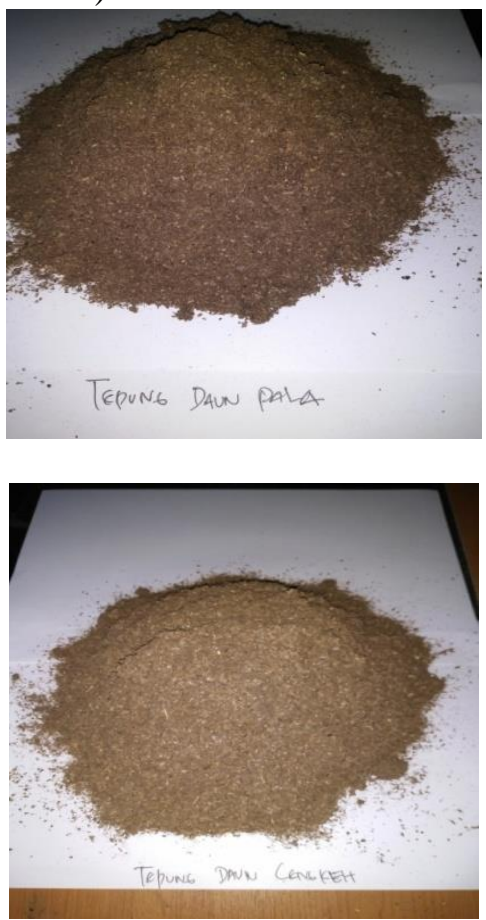

Gambar 5. Tepung buah Pala (Myristica frangrans Houtt) dan Cengkeh (Syzygium

aromaticumL) yang dijadikan sebagai fitobiotik pada kegiatan IPTEKDA LIPI di Desa Akekolano.

\subsection{Jumlah ternak broiler}

Kegiatan IPTEKDA LIPI telah berlangsung dari awal Februari Sampai dengan November 2016 telah melakukan pemeliharan sebanyak lima periode dengan kapasitas produksi per periode pemeliharaan sebanayak 1000 ekor. Adapun jumlah ternak broiler selama pemeliharaan di tahun pertama (periode Februairi sampai dengan November 2016) dapat dilihat pada Tabel 1 . 
Tabel 1. Data jumlah ternak broiler periode Januari November 2016.

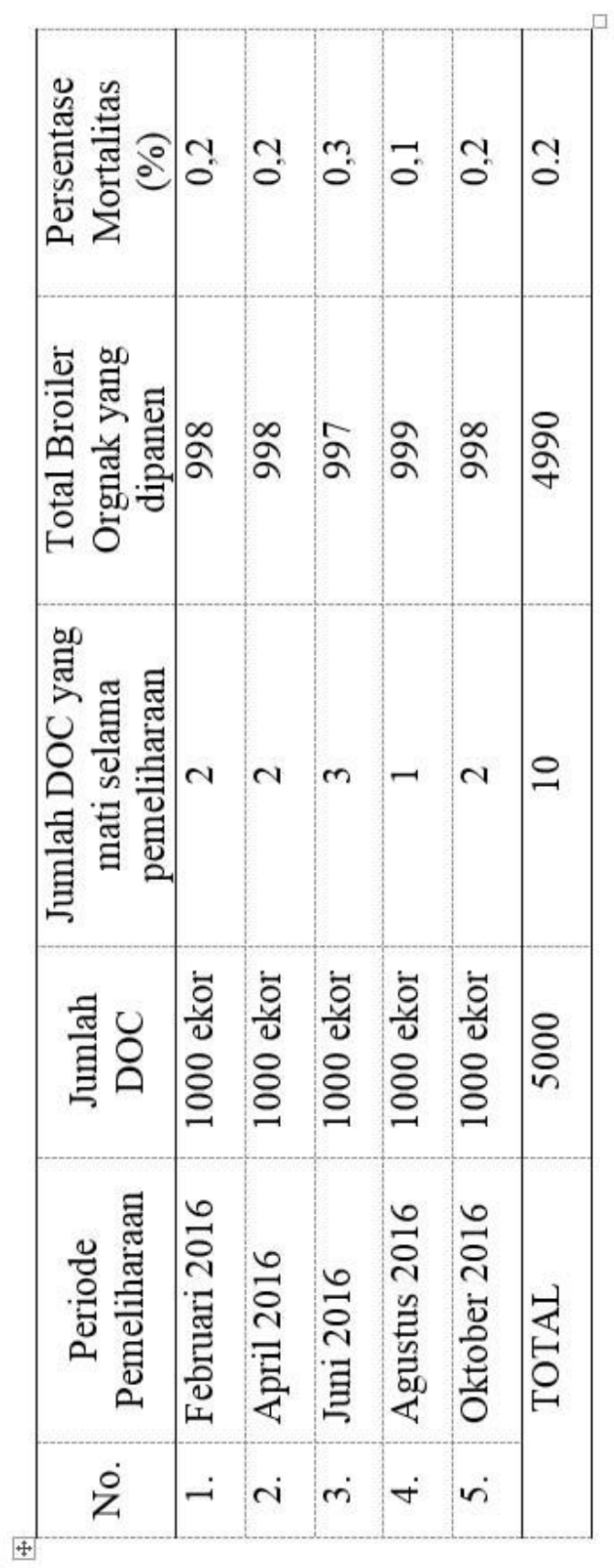

Berdasarkan Tabel 2. terlihat bahwa sampai dengan Oktober 2016 jumlah total broiler organik yang dipelihara sampai panen sebanyak 4990 ekor dimana pada periode Februari-Maret sebanyak 998 ekor, April-Mei sebanyak 998 ekor, periode Juni-Juli sebanyak 997 periode Agustus-September 999 ekor dan periode Oktober-November sebanyak 998 ekor.
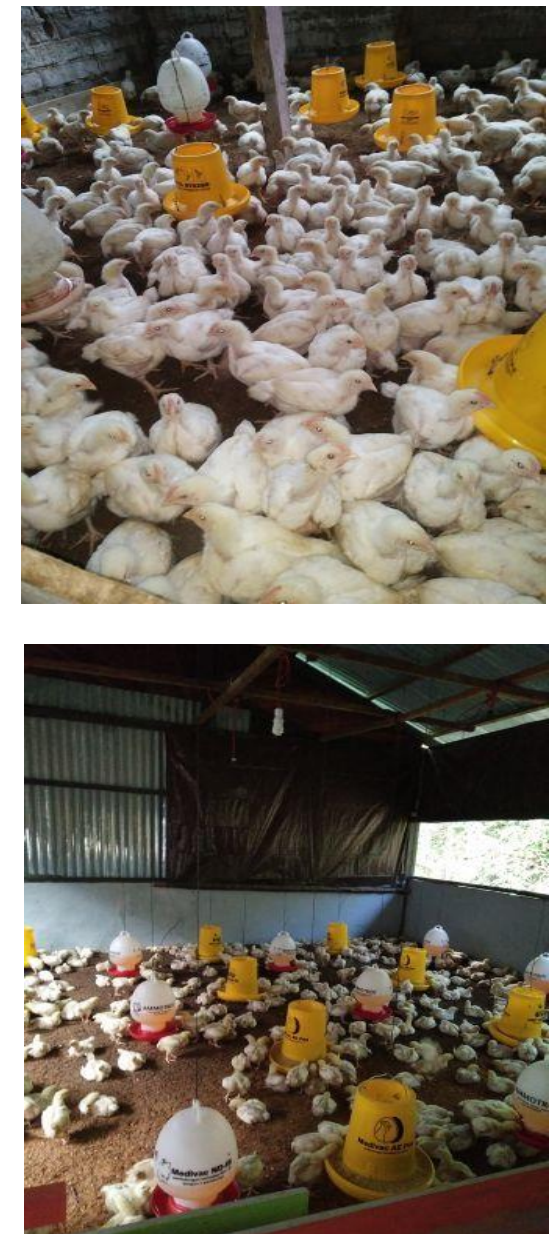

Gambar 2. Pemeliharaan ayam broiler

Selama pemeliharaan, ternak broiler diberi pakan yang ditambahkan tepung daun cengkeh dan tepung buah pala dengan persentase $2 \%$ dari total pakan. Pemberian tepung daun cengkeh dan tepung buah pala ini sebagai fitobiotik dengan tujuan untuk meningkatkan produksitifitas ternak broiler. Seperti yang dilaporkan Sapsuha, dkk 2015 bahwa pemberian daun cengkeh dan daun pala masing-masing $2 \%$ serta kombinasinya dapat meningkatkan pertambahan berat badan ternak broiler.

Selain pemberian tepung daun cengkeh dan tepung buah pala, selama kegiatan berlangsung diberikan pemberian isolasi bakteri Lactobacillus sp dari usus ayam broiler kedalam air minum sebanyak $1 \mathrm{ml}$ dalam $1000 \mathrm{ml}$ hal ini dilakukan dengan tujuan untuk efisiensi produksi. Seperti yang dilaporkan Sapsuha, dkk (2015), bahwa Pada kelompok perlakuan R1 yaitu dengan penambahan $1 \mathrm{ml}$ isolasi bakteri Lactobacillus sp 
dari usus ayam broiler kedalam air minum menunjukan pertambahan berat badan yang paling baik yaitu sebesar 1401 gr/ekor, sedangkan yang paling rendah terdapat pada perlakuan $\mathrm{R} 0$ atau kontrol dengan rataan 1251,0 gram/ekor.

\section{KESIMPULAN DAN SARAN}

\subsection{Kesimpulan}

Kegiatan IbIKK yang telah dilaksanakan dapat disimpulkan bahwa pemeliharaan ternak broiler telah dilakukan sebanyak lima periode dengan jumlah broiler organik yang telah dipanen sampai dengan November 2016 sebanyak 4990 ekor dengan harga jual Rp. 35.000/ekor dengan total penjualan broiler organik sebanyak $\mathrm{Rp}$. 174.650.000

\subsection{Saran}

Pemanfaatan tanaman herbal sebagai tepung (daun cengkeh dan buah pala) sebagai fitobiotik pengganti antibiotik perlu digunakan dalam industri peternakan khususnya ternak broiler agar dapat mengurangi residu antibiotik produk yang dihasilkan.

\section{UCAPAN TERIMA KASIH}

Ucapan terima kasih disampaikan kepada DP2M DIKTI yang telah menyetujui dan mendanai kegiatan pengabdian ini, kepada Bapak Rektor Universitas Khairun, Ketua Lembaga Pengabdian pada Masyarakat, bapak Dekan Fakultas Pertanian dan Ketua Laboratorium Peternakan yang telah menfasilitisasi dan mendukung terlaksananya kegiatan pengabdian ini.

\section{REFERENSI}

Conway, P.L. and X. Wang. 2000. Specifically targeted probiotic can reduce antibiotic usage in animal production. Asian-Aus. J. Anim. Sci. 13.Supp : 358 - 361.

Lopez, P., C. Sanchez, R. Badle, and C. Nerin. 2005. Solid-and vapor-phase antimicrobial activities of six essential oils: Susceptibility of selected foodbome bacterial and fungal strains. J. Agr. FoodChem.53: 6939 - 6946.

Panda, A.S.R. Rao, and M. Raju. 2009. Phytobiotics, a natural growth promoter Poultry International pp: $10-11$.
Sapsuha, Y dan Nur Sjafani. 2011. Teknologi tepung daun untuk industri pakan berbasis sumberdaya lokal di Maluku Utara, Jurnal Cannarium Vol. 12 No. 2 , Universitas Khairun Ternate.

Sapsuha, Y., Utami, S dan Lestari, S. 2015. Pengunaan tanaman herbal sebagai feed additive untuk Meningkatkan produktivitas broiler. Laporan penelitian, LPPM Universitas Khairun Ternate.

Ulfa, M. 2006. Potensi Tumbuhan Obat Sebagai Fitobiotisticik Multi Fungsi Untuk Meningkatkan Penampilan dan Kesehatan Satwa di Penangkaran.Media Konservasi 10 (3): 109 - 114.

Windisch, W.K. Schedle, C. plitzner, and A. Kroisnayr. 2008. Use of phytogenic products as feed additives for swine and poultry. J. Anim. Sci. 86: E140 - E148.

\section{REFERENSI}

Badan Pusat Statistik. 2013; Kendala utama UMKM berdasarkan sensus UMKM 2012. (Diunduh 14 Juni 2014); Tersedia Pada www.bps.go.id.

Kementrian Koperasi dan UKM. 2013; Sektor UMKM Menyerap 97,3 persen Dari Total Tenaga Kerja Indonesia; [Diunduh 12 Juni 2014]; Tersedia pada: http://www.sindotrijaya.com/ news/detail/3910/sektor-umkm-menyerap973-dari-total-tenaga-kerja indonesia\#. UrLo8OJWhds.

Subiyanto, Rachmad; 2013; UMKM: Keterbatasan Modal Jadi Kendala Pertumbuhan Usaha, bisnis.com, Balikpapan, Kalimatan Timur; (Diunduh 14 Juni 2014). Tersedia Pada: http:// usahamodalkecil31.blogspot.co.id/2012/08/ kendala-usaha-kecil-menengah-dan-solusi. html.

Ismawan B. 2013; Sebuah upaya perguruan tinggi mengatasi kemiskinan melalui pengembangan usaha mikro. Teти Nasional Penanggulangan Kemiskinan 2013 [Internet]; Depok (ID). hlm 1; [Diunduh 14 Juni 2014]. Tersedia Pada http://www.ui.ac.id/id/news/archive/6883 